University of South Florida

DIGITAL COMMONS

Digital Commons @ University of

@ UNIVERSITY OF SOUTH FLORIDA

South Florida

QMaSC: A Handbook for Directors of

Quantitative and Mathematics Support Centers

USF Libraries

$1-1-2016$

\title{
26. Case Study: The William B. Law Learning Commons at Tallahassee Community College
}

Vera L. Mayes

Tallahassee Community College

Follow this and additional works at: https://digitalcommons.usf.edu/qmasc_handbook

\section{Recommended Citation}

Vera L. Mayes (2016), "Case Study: The William B. Law Learning Commons at Tallahassee Community College", http://dx.doi.org/10.5038/9780977674435.ch26 in G. Coulombe, M. O'Neill, M. Schuckers (Eds.) A Handbook for Directors of Quantitative and Mathematical Support Centers, Neck Quill Press, http://scholarcommons.usf.edu/qmasc_handbook.

This Case Studies is brought to you for free and open access by the USF Libraries at Digital Commons @ University of South Florida. It has been accepted for inclusion in QMaSC: A Handbook for Directors of Quantitative and Mathematics Support Centers by an authorized administrator of Digital Commons @ University of South Florida. For more information, please contact digitalcommons@usf.edu. 


\section{Case Study: The William B. Law Learning Commons at Tallahassee Community College}

(c) Vera L. Mayes,

Tallahassee Community College

प्र

\section{Introduction to the Center}

\section{Program History}

Tallahassee Community College, located in Tallahassee, Florida, serves approximately 14,000 students. TCC offers A.A. and A.S. degrees and certificate programs. The college has partnerships with five universities, making it possible to obtain a four-year degree on the TCC campus.

Until 2008, Tallahassee Community College had four separate learning centers: The Reading Center, the English Skills Center, the Math Center, and the Writing Center. The Reading and English Skills Centers were designed to serve only students enrolled in Academic Support (Developmental) classes. The Math Center and the Writing Center were designed to serve the entire campus. Five years ago, the centers were joined in a centrally located building that had been redesigned to house all four of them. Because the Learning Commons was designed to serve the entire campus, other services were added, including academic computing (open access computers), as well as student success advising. The Library is co-housed in the same facility.

\section{Program Location and Facility}

The Learning Commons adjoins the Library and is centrally located on campus next to the Student

Suggested Citation: Vera L. Mayes (2016), "Case Study: The William B. Law Learning Commons at Tallahassee Community College", http://dx.doi.org/10.5038/9780977674435.ch26 in G. Coulombe, M. O'Neill, M. Schuckers (Eds.) A Handbook for Directors of Quantitative and Mathematical Support Centers, Neck Quill Press, http:// scholarcommons.usf.edu/qmasc_handbook.

This material is based upon work supported, in part, by the National Science Foundation under Grant DUE1255945. Any opinions, findings, and conclusions or recommendations expressed in this material are those of the author(s) and do not necessarily reflect the views of the National Science Foundation 
Union and the main administration building. It is divided into two floors, with the content areas of math, science, accounting, and computer programming served on the first floor and the communications areas of reading, English, writing, and ESOL (English as a Second Language) served on the second floor.

A portion of an existing building on campus was redesigned specifically as a one-stop learning assistance facility. It is a well-lit, thirty-five thousand square foot, comfortable space with a variety of types of seating, flexible table arrangements, six study rooms, three classrooms, staff offices, and a multitude of computers for student use. The Writing Area is located in the Library section of the building next to the Reference Department to facilitate collaboration between the two areas.

The Specialists' (content area) offices are centrally located and designed in an open format to foster collaboration among the staff.

\section{Program Objectives}

The TCC Learning Commons strives to be a comprehensive, integrated learning center that provides assistance and resources to all TCC students. The Learning Commons offers students and faculty a broad range of services, including diagnostic assessments, learning materials, electronic resources, individual conferences, one-on-one and small group tutoring, whole-class support, workshops and seminars, success strategies, technology support, and individual learning plans. Throughout the Learning Commons, students have open access to computers, computer applications, and technology support. Tutoring is available in a range of content areas, including math, science, accounting, economics, reading, writing, language skills and support for non-native speakers of English. Distance delivery of learning resources is provided by the Learning Commons web site. A searchable portal site, the new Virtual Learning Commons, launched a beta version in the fall of 2013.

Services and resources are available in a variety of modes to meet different learning styles and demands of students. The aim of the Learning Commons is to be proactive in helping students identify their learning needs and then use the resources and services that are available to improve their academic performance. The Learning Commons fulfills its mission by its commitment to high academic standards; effective use of technology; integration of resources and support services; just-in-time delivery of services; a diverse, trained and professional staff; and faculty participation and confidence.

\section{Center Organization and Services}

\section{Reporting Lines}

The Learning Commons is a separate entity on campus as part of a recent reorganization plan. In 2013, the school created a new position, Director of the Learning Commons, who reports to the Provost of the College and is part of the executive team of the college. The two Learning 
Commons Coordinators (one for Math and Science, one for Communications) report to the Director. The Provost, in turn, reports directly to the college president. The College president reports to the Board of Trustees, which is responsible for establishing college-wide positions and funding. Each floor of the Learning Commons has a coordinator and an assistant coordinator. Content area specialists bring curriculum knowledge, best practices in education, technology expertise and the ability to work across campus with faculty and staff. Other Personal Services (OPS) staff members are hourly, temporary employees hired to flesh out content areas as well as meet peak demand time frames, and serve as receptionists. All OPS staff and content area specialists report to the coordinator or assistant coordinator on their floor. The specialists assist the coordinator in supervising and training the work-study student staff (mostly receptionists) and OPS tutors. In addition, a specialist for technology is located on each floor, and both supervise the OPS people responsible for providing technology assistance.

\section{Sources of Funding}

The College General Fund provides most of the funds for tutoring and technology. Some of the tutors are paid through Perkins funds for specific content areas. Some of the student staff members qualify for the Federal Work-Study Program.

\section{Services and Students Served}

Learning Commons' services include content area tutoring in math, science, accounting, economics, computer programming, computer software assistance, reading, English skills, writing, ESOL skills, and a variety of other areas depending upon faculty volunteers from various departments on campus. Assistance includes self-help, brief staff-assisted, and intensive staff-assisted services to assist students in improving their academic performance. Drop-in services come with support provided by staff members, if needed. Students can have half-hour writing conferences, and several of the gateway math courses can have one-on-one or small group conferences available to them, too. Developmental courses at the first level in math, reading, and English skills have weekly labs that provide faculty-guided use of learning resources in a classroom setting, as well as staff-guided use of learning resources.

The Learning Commons was designed to encourage student collaboration. Students frequently use the commons to meet in small, collaborative working groups to learn and to apply specific academic skills, with staff support provided when needed. Furniture can be easily rearranged, computers are placed in pods to better facilitate project collaboration, and moveable whiteboards are available throughout the space. Study rooms are also available for student study groups or for quiet independent study.

Workshops are offered that involve presentations by staff or faculty members on content knowledge or on topics related to improving student academic performance; these workshops may include 
guided group use of learning resources.

The Learning Commons is open to all TCC students. In addition, students enrolled in other programs on campus, such as High School Equivalency Diploma Program (GED), Adult Basic Education (ABE), and the University Partners (Barry University, Flagler University, Embry-Riddle Aeronautical University and Saint Leo University), are also permitted to use the services that are provided by the Library/Learning Commons.

\section{Staffing, Hiring, and Training}

\section{Staffing}

Permanent staff of the Learning Commons includes a Director, two Coordinators (one for each floor), an Assistant Coordinator on each floor, and Learning Specialists whose content areas match those of the content tutoring provided. Temporary staff includes OPS tutors that cover content and technology needs, receptionists, and work-study students. There are approximately 100 employees during a typical semester.

All professional staff members have degrees that reflect their content area and are chosen because they demonstrate the ability to mentor and train the OPS staff. They are also required to have a minimum of one year of teaching experience or experience in a learning center.

Some of the developmental classes have labs that meet weekly in the Commons, and Learning Commons' staff assists during these sessions. In addition, faculty members are encouraged to host some of their office hours in the Commons so students can meet them on a common ground. Faculty members also help by presenting review workshops, especially for math and science courses, just

prior to final exams. Staffing levels are based on usage and demand. Although writing conferences are available at all times when the Commons is open, tutoring for other content areas is not and the staff for those areas have specific availability schedules, which are posted in-house and on our website.

\section{Hiring}

Permanent staff members in the Learning Commons are hired after being recommended by a selection team (led by the appropriate coordinator) and finalized by the recommendation of the Director. The Learning Specialists take a content test in their chosen area to ascertain their current level of ability. These are board-approved positions, and they are evaluated on a six-month, and then a yearly, basis. OPS applicants take tests in their chosen content fields, must have two recommendation letters, and must pass an interview that examines their philosophy and ability to tutor their content area. Their ability to communicate clearly is also evaluated during the interview. The screening tests that the potential OPS tutors take in the qualitative areas have been designed 
in coordination with the faculty, so they have a high degree of influence on the quality of the tutors hired.

\section{Training Guidelines}

Training in the Learning Commons is based on the CRLA (College Reading and Learning Association) model. We are currently certified at Levels I, II, and III. This means that the topics must meet CRLA criteria as a minimum, but we can still add other topics as we deem them appropriate. Training is mandatory in the Commons. After tutors complete the required Levels I and II, they are then put in what we call the $2+$ group. This level continues their professional development, and allows them to develop a project each semester that will benefit the Commons. Level III is by application and acceptance only. The first semester of Level III is based on the CRLA topics, and the second semester is an internship.

A training day is scheduled at the beginning of each semester involving issues of concern for all tutors. It includes cross-training between floors to better serve students and faculty. Training day includes information about the specific content areas, as well as activities designed to foster relationships throughout the Commons. External consultants are sometimes needed and hired to provide specialized training for resources or services. Staff training continues throughout the semester on a regular basis, either weekly or bi-weekly, depending upon the content area. Since there are so many staff members to train, each floor divides its staff into small groups or cohorts. Cohorts meet weekly or bi-weekly, depending upon the level and the number of topics to be covered. Time is tracked and entered into a database designed specifically to track topics, length of time, mode, and completion of tasks, to determine if requirements have been met. [1]

Learning Specialists or coordinators are designated as training facilitators. Presentations are done by a variety of individuals including the facilitators, faculty, other campus staff and the tutors themselves. Some training assignments are done online, or as specific writing assignments. The presentations are based either on best practices in training, leadership or mentoring or on specific content areas as guided by CRLA requirements. The Learning Commons developed a WIKI where staff can define CRLA topics, develop lesson plans, define learning outcomes for each session, and develop ways to assess those outcomes. The training facilitators for each cohort can easily access the lesson plans and materials for each training session. In this way, we are assured that the same material is presented to all cohorts. In addition, this practice stores information that is readily accessible for tutors to make up missed sessions. Tutors and staff are given the opportunity to evaluate sessions and to provide input for future sessions. 


\section{Community Interactions}

The Commons' permanent staff members serve on a variety of committees and initiatives across campus, including grant initiatives and leadership committees. The staff participates in campus trainings along with faculty and other staff on campus, and they are sometimes called upon to do presentations across campus. Each staff member serves as a liaison with both full-time and parttime faculty. They meet with faculty members to discuss resources, the needs of their students, and what is needed in the Commons to support what is done in the classroom. Because the Commons/library is a hub for students, the campus police make a point of routinely patrolling the facility to keep it a safe place. Support from all units on campus is critical to keep the facility functional and attractive. As mentioned before, the Learning Commons is open to all TCC students, including students enrolled in other programs on campus.

\section{Assessment at the Center}

The Learning Commons was developed in part because the data collected showed the need for more space and resources. A powerful part of the data showed the effect that the old centers had on success rates.

Data are collected on number of visits, length of visits, time of day, and classes. The data are fed into the college's mainframe so that reports can be run to meet a variety of needs. The IT team has developed some basic reports that pull student data from the mainframe together with attendance data from Accutrack. Table 1 gives a snapshot of Usage of the Learning Commons and Its Growth [2]

Table 1: Snapshot of Usage of the Learning Commons and Its Growth, 2]

\begin{tabular}{|l|r|r|}
\hline & Fall 2008 & Fall 2012 \\
\hline Weekly average number of visits & 3,995 & 6,482 \\
Courses supported & 220 & 383 \\
Unique students & 7,180 & 8,454 \\
*otal Visits & 62,388 & $* 100,475$ \\
\hline Prior to combining in one facility, this was the level of usage \\
for all four centers combined in one year.
\end{tabular}

When the cohort data does not show a positive correlation between success and visits, the Commons' staff will investigate resources still needed. They will also collaborate with faculty to look at continued student needs. In addition, other data such as usage of resources and attendance at workshops is collected and analyzed. Yearly reports track interactions with faculty, types of technology available, divisions that are collaborated with, along with modes of resources for each division and course. 
Table 2: Comparison of Success Rates, [3]

\begin{tabular}{|l|r|r|}
\hline & \multicolumn{2}{|c|}{ Fall 2012} \\
\hline & $\begin{array}{r}\text { Pass Rate } \\
\text { no conferences }\end{array}$ & $\begin{array}{r}\text { Pass Rate } \\
3+\text { conferences }\end{array}$ \\
\hline Core English classes & $68 \%$ & $90 \%$ \\
\hline
\end{tabular}

\begin{tabular}{|l|r|r|}
\hline & $\begin{array}{r}\text { Pass Rate } \\
\text { no visits }\end{array}$ & $\begin{array}{r}\text { Pass Rate } \\
3+\text { visits }\end{array}$ \\
\hline Core Math/Science classes & $57 \%$ & $70 \%$ \\
\hline
\end{tabular}

Table 3: Fall 2011 Success Data Based on Use of Anatomy Models in the LC, 3]

\begin{tabular}{|l|r|r|r|}
\hline & No Checkouts & $1-3$ Checkouts & $4+$ Checkouts \\
\hline BSC2085L & $54.4 \%$ & $72.2 \%$ & $81.8 \%$ \\
\hline BSC2086L & $81.7 \%$ & $82.1 \%$ & $94.4 \%$ \\
\hline
\end{tabular}

Both student and faculty surveys are used to determine satisfaction with services and to determine future needs. The surveys allow the staff to see if students feel that they are given strategies, not just answers, in their interactions with staff. The surveys ask faculty members if the Learning Commons has sufficient resources for their courses. An official program review just implemented on campus will also include the Learning Commons as a unit. It will track the success of the Commons in meeting goals, and will be repeated every three years. In addition, one of the college's main QEP (Quality Enhancement Plan) goals has included the Learning Commons and the support for students that it provides, so that the Southern Association of Colleges and Schools (SACS) reports include data from the Learning Commons. The Learning Commons retains an advisory team that consists of staff, faculty and administrators. This group meets once a semester and considers feedback from the different divisions and across campus. It also allows the staff to highlight new services and talk about needs on an ongoing basis.

\section{What Makes the Learning Commons Unique?}

The faculty and students on campus embrace the Learning Commons. Since opening five years ago, usage jumped astronomically (in the math area alone: 242\%) and the faculty presence has increased. Faculty work with the staff to determine ways that the commons can help students get access to resources such as textbooks, handouts, anatomy models, and calculators. Since the goal is to help students develop into more independent learners, it is a great collaboration. The faculty also host review sessions or bring classes over for orientation or tours. The campus feels that this is a good resource and is receptive when asked to help support the Commons.

Another goal of the Learning Commons is to have a diverse staff, this includes diversity in 
educational background as well as ethnicity. This goal stems from matching the college's mission of diversity. The college has students from 86 different countries and actively recruits globally. It recently set up an International Students Services office to assist these students with their unique challenges. The administration also understands how important this academic support is to the students and to the college's efforts at retention. Even when budgets have been cut and positions have not been refilled in other areas across campus, this has not been the case in the Commons.

Representatives often visit the Commons from other colleges and universities to see how all the services and resources have been pulled together, and the Commons is used as a model. Elected representatives have visited to see how the monies are being used, and they are delighted to see students using the facility and the resources. Data show that since the Commons started five years ago, the retention and graduation rate across campus has increased by two percent. Students and their usage continue to be tracked to help justify requests for new space, increased budgets, and new positions. The Learning Commons will need to adjust to a new house bill that takes effect in the fall of 2014 and restructures developmental instruction in Florida. Data will be used to build a case and to ask for new money to support new services.

One of the last things that we feel makes us unique is that we are never done. We add new resources and services every year. We try to be responsive to students and their requests for services. We are always searching for excellence.

\section{Bibliography}

[1] V. Mayes, G. Schaberg, and M. Hamilton, "CLRA application, level 2," 2013.

[2] V. Mayes, S. Sampson, G. Schaberg, and M. Hamilton, "Learning commons end of year report 2012/2013," 2013.

[3] V. Mayes, S. Sampson, G. Schaberg, and M. Hamilton, "Learning commons end of year report 2011/2012," 2012. 